\section{Tomasz Tułodziecki}

Uniwersytet Mikołaja Kopernika, Toruń

thomast@umk.pl

ORCID: 0000-0002-7650-8543

DOI: http://dx.doi.org/10.12775/BPTh.2018.010
Biblica

et

Patristica

Thoruniensia

11 (2018) 2: 197-207

ISSN (print) 1689-5150

ISSN (online) 2450-7059

\title{
Jonasz jako świadek diaspory asyryjskiej
}

\section{Jonah as a witness to the Assyrian diaspora}

\begin{abstract}
Streszczenie. Dotychczasowe wysiłki egzegetów nad ustaleniem precyzyjnej datacji Księgi Jonasza nie przyniosły pożądanego rezultatu. Przytoczone w tej naukowej dyskusji argumenty są czystą spekulacją i ciągle budzą wątpliwości. Problem datacji jest bardzo istotny. Bez ustalenia epoki, z której pochodzi dany tekst, nie można go właściwie zinterpretować. Na podstawie dotychczasowych badań nad Księgą Jonasza trudno także pozytywnie odpowiedzieć na pytanie, czy prorok Jonasz miał związek z samą Niniwią i mieszkającymi w Asyrii uprowadzonymi do niewoli Izraelitami. Ponieważ dotychczasowe prace nad datacją tekstu o Jonaszu zawodzą, należy spojrzeć na jej treść z innej perspektywy. Analizy winny dotyczyć rzeczywistości, której dotyka Księga Jonasza, które należy skonfrontować z danymi historycznymi w historii biblijnego Izraela i starożytności w ogóle. Dzięki takiemu podejściu do bieżącego tekstu Jonasza można wyciągnąć wniosek, że wydarzenia opisane w tym opowiadaniu odzwierciedlają najlepiej wydarzenia przystające do epoki perskiej, a dokładnie do czasów reform religijnych przeprowadzanych przez biblijnych bohaterów: Nehemiasza i Ezdrasza. Na tle tych wydarzeń widać najlepiej podstawową tematyką ukazaną w dziele Jonasza: dyskusję nad rolą pogan w nowej wspólnocie Izraela budowanej po niewoli babilońskiej i aktualność idei uniwersalizmu zbawczego obecnego także w innych dziełach powygnaniowych.
\end{abstract}

\begin{abstract}
The exegetes have not been successful so far in determining the precise date of the creation of the Book of Jonah. The arguments presented in this academic debate are pure speculations and still arise many doubts. However, the problem of the date is crucial as without establishing the time from which the text comes it is not possible to interpret it correctly. Relying on the current research on the Book of Jonah it is difficult to answer positively the question whether Jonah was linked with Nineveh and with enslaved Israelites living in Assyria. As the current research on the date of the creation of the Book of Jonah has failed, it is necessary to look at the text from a different perspective. The analyses should concentrate on the reality described in the Book of Jonah which must be confronted with the historical data of biblical Israel and antiquity as such. Such an approach to the text allows us to draw a conclusion that the events described in the narrative best reflect the events from the Persian epoch and, to be more precise, from the time of religious reforms by the biblical characters, such as Nehemiah
\end{abstract}


and Ezra. Against the background of these events the main themes from the Book of Jonah are best visible, for example the discussion on the role of pagans in the new community of Israel created after the Babylonian captivity and the timeliness of the idea of salvific universalism which is also present in other texts created after the exile.

Słowa kluczowe: Jonasz; prorok; diaspora; Niniwa; Asyria; historia; Persja; okres; czas.

Keywords: Jonah; prophet; diaspora; Niniveh; Assyria; history; Persia; period; time.

\section{Wprowadzenie}

d kilkunastu lat trwa w polskiej egzegezie ożywiona dyskusja na temat istnienia i charakteru ewentualnej diaspory izraelskiej utworzonej z uprowadzonych do niewoli mieszkańców północnej monarchii i osiedlonych w różnych rejonach wielkiego asyryjskiego imperium. Szczególnie cenny głos w tej dyskusji należy do ks. prof. Waldemara Chrostowskiego ${ }^{1}$ i ks. prof. Wojciecha Pikora $^{2}$. Chociaż w swoich publikacjach prezentują oni przeciwstawne stanowiska na temat ewentualnego istnienia wspólnoty Izraelitów na wygnaniu po 721 roku przed Chrystusem, to jednak jej śladów poszukują, opierając się na tym samym tekście biblijnym. Są to wybrane teksty z Księgi proroka Ezechiela. Niniejszy artykuł nie podejmuje polemiki z prezentowanymi stanowiskami wspomnianych biblistów, lecz stanowi próbę poszukiwania podobnych śladów diaspory Izraelitów w Asyrii w tekście innego proroka, który, jak wynika z tekstu jego księgi, bezpośrednio zetknął się z mieszkańcami asyryjskiej stolicy. Wśród proroków ST, jedynym, który według przekazu biblijnego, znalazł się bezpośrednio na terenie Asyrii był Jonasz, syn Amittaja. Warto więc zapytać, na ile to wyjątkowe opowiadanie może pomóc w ustaleniu ewentualnych śladów

1 Należy pamiętać, że W. Chrostowski poruszał temat izraelskiej diaspory w Asyrii w kilku publikacjach, które bazują na tekście Księgi Ezechiela. Najważniejsze z nich to: Ezechiel jako świadek asyryjskiej diaspory Izraelitów, w: W. Chrostowski, Asyryjska diaspora Izraelitów $i$ inne studia, RSB 10, Warszawa 2003, s. 55-68; „Wizja ożywienia wyschniętych kości (Ez 37,1-14) jako świadectwo asyryjskiej diaspory Izraelitów”, CT 77/4/2007, s. 21-48. Należy pamiętać, że W. Chrostowski poszukuje śladów diaspory izraelskiej w Asyrii nie tylko w tekstach z Księgi Ezechiela, czego przykładem jest publikacja: W. Chrostowski, Ksiega Nahuma jako świadectwo asyryjskiej diaspory Izraelitów, w: idem, Asyryjska diaspora Izraelitów i inne studia, RSB 10, Warszawa 2003, s. 69-98.

2 Por. W. Pikor, W poszukiwaniu asyryjskiej diaspory Izraelitów, s. 285-334. 
izraelskiej wspólnoty przede wszystkim w samej Niniwie, mieście szczególnej misji Jonasza.

\section{Dyskusja nad historycznym Jonaszem}

Wśród ksiąg prorockich ST Księga Jonasza zajmuje miejsce wyjątkowe. Dotyczy to zarówno stylu, jak i treści oraz przesłania, jakie z niej wypływa. Zaskakujący jest już sam fakt, że w żadnym fragmencie tego dzieła tytułowy bohater nie jest nazywany prorokiem. Tytuł ten w ogóle nie pojawia się w tekście opowiadania. W porównaniu z innymi dziełami prorockimi Księga Jonasza nie zawiera także obszernych mów prorockich, przepowiedni i wyroczni. Nie jest ani typową historią, ani biografią prorocką. Według większości egzegetów mamy tu do czynienia z nowelą, bądź tzw. teologicznym opowiadaniem prorockim. Ponieważ w tekście Księgi Jonasza występuje spora liczba aluzji i cytatów ze ST, widziano w niej także formę midraszu haggadycznego ${ }^{3}$. Jedynym wyjątkiem w całej Księdze Jonasza jest słowo przepowiedni o zburzeniu asyryjskiej stolicy po czterdziestu dniach: „Jeszcze czterdzieści dni, a Niniwa zostanie zburzona" (Jon 3,4). Być może ta jedyna wyrocznia w tekście księgi, jak również tradycyjne utożsamianie Jonasza syna Amittaja, proroka posłanego do Niniwy,

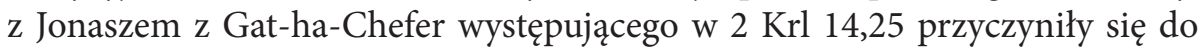
włączenia Księgi Jonasza do biblijnego kanonu ksiąg prorockich ${ }^{4}$.

Istnienie historycznego Jonasza, mieszkającego w Królestwie północnym za czasów Jeroboama II, na przełomie IX i VIII wieku przed Chrystusem, przyjmowane jest przez wielu egzegetów za pewnik historyczny. Należy zauważyć, że w przypadku Jonasza kwestie biograficzne, czas powstania księgi oraz jej autorstwo są ze sobą ściśle powiązane. Chociaż nie posiadamy zbyt wielu kryteriów zewnętrznych mogących potwierdzić realne istnienie Jonasza z Get-ha-Chefer, który udał się z misją do Niniwy, to jednak przytoczenie jego imienia w czasach działalności tak ważnych osobistości prorockich, jak Ozeasz, Amos czy mężowie Boży Elizeusz i Eliasz przemawia za historycznością tej postaci. Według T. Brzegowego musiał on być postacią wybitną swej epoki, a pamięć o nim zachowana wśród uczniów zaowocowała stworzeniem historii, na wzór opowiadań o anonimowym proroku z Judy, który przybył do Betel napomnieć Jeroboama (1 Krl 13); ucieczce Eliasza na Pustynię Judzką (1 Krl 19), czy historii uzdrowienia Naamana przez proroka Elizeusza $(2 \mathrm{Krl} 5)^{5}$.

3 Por. U. Struppe, Bie Bücher Obadja, Jona, s. 59.

4 Por. E. Zenger, Das Zwölf Prophetenbuch, s. 498.

5 Por. T. Brzegowy, Heksameron i inne studia nad Starym Testamentem, s. 606. 
Według tego samego autora nie można wykluczyć również historycznego pobytu Jonasza w stolicy imperium asyryjskiego, Niniwie. Tak jak prorok Elizeusz został posłany do starożytnego Damaszku, tak Jonasz mógł odwiedzić Niniwę. Wiadomo z danych historycznych, że zarówno królowie Izraela, jak i Judy zmuszeni byli utrzymywać poddańcze relacje z Asyrią. Już w roku 841 król Jehu zapłacił daninę i złożył wasalski hołd królowi Salmanassarowi III. $\mathrm{Z}$ tego czasu zachowała się rycina, która jest jedynym graficznym przedstawieniem izraelskiego władcy w starożytności. Haracze i trybuty władcy Izraela płacili Asyrii także w roku 802 i 738. Także Ozeasz, jeden z ostatnich królów Izraela, posłał trybut Tiglat-Pileserowi III w roku 732, czyli na krótko przed upadkiem państwa północnego ${ }^{6}$. Wszystkie te fakty historyczne zakładają kontakty dyplomatyczne i podróże Izraelitów do Asyrii, w których mógł uczestniczyć biblijny Jonasz, syn Amittaja.

W swojej historii Izrael dwukrotnie doświadczył morderczego wpływu Asyrii, który zaznaczył się w dziejach tego państwa podwójną deportacją mieszkańców północnej monarchii nad potok Kebar w dorzeczu Tygrysu i Eufratu (732 i 722r. przed Chr.). Dodatkowo Asyryjczycy zasiedlili opuszczone przez Izraelitów tereny pogańskimi plemionami, pochodzącymi z najdalszych prowincji imperium (2 Krl 17). W obliczu tych tragicznych wydarzeń w sercach mieszkańców północnego Królestwa rodziły się pytania o kres czasów ucisku i prześladowań. Nie brakowało także głosów i pytań o możliwość nawrócenia Asyryjczyków, Niniwitów w szczególności, zwłaszcza w kontekście nauki o powszechności Bożego miłosierdzia dla wszystkich, którą głosił prorok Ozeasz. To właśnie z tym przesłaniem, mimo wewnętrznego dramatu i osobistego braku zgody na dar miłosierdzia dla pogan, wyruszył Jonasz do asyryjskiej stolicy.

W tym kontekście rodzi się kilka pytań, na które spróbujemy odpowiedzieć w niniejszym artykule. Kwestią podstawową jest pytanie o możliwość pobytu samego Jonasza w Niniwie. Sprawą dyskusyjną jest również ustalenie autora tekstu opowiadania o Jonaszu. Czy jest nim prorok, który głosił Słowo Boga w Niniwie, czy też jego ustny przekaz został z czasem odpowiednio zredagowany i przedstawiony w formie spisanej przez ewentualnych spadkobierców jego myśli (uczniów lub szkołę redaktorów)? Jeśli przyjmiemy, że Jonasz, syn Amittaja, jest Jonaszem z Gat-ha-Chefer, to pobyt proroka na terytorium asyryjskim przypadłby na czasy sprzed deportacji Izraelitów, czyli przed rokiem 732. Jonasz z Gat-ha-Chefer żył bowiem w czasach Jeroboama II, kiedy zagro-

6 Spekulując na temat możliwego pobytu Jonasza w Niniwie, T. Brzegowy nie opowiada się jednoznacznie za przyjęciem tej teorii. W dyskusji, jaką prowadzi, zaznacza, że istnieją takie hipotezy, przytaczając jednocześnie szereg argumentów, które wykluczają możliwość pobytu proroka Jonasza w stolicy Asyrii. Ibidem, s. 610-612. 
żenie asyryjskie nie wróżyło jeszcze narodowej katastrofy Izraela. Tym samym Jonasz z Gat-ha-Chefer nie mógł być świadkiem diaspory asyryjskiej Izraelitów z tej przyczyny, że takowa jeszcze nie istniała. Sama zaś Niniwa nie była jeszcze w tym czasie stolicą Asyrii. Skąpe dane biblijne na temat proroka Jonasza idą także $w$ parze $z$ brakiem świadectw zewnętrznych (pozabiblijnych) na temat osoby proroka ${ }^{7}$. Z powodu braku innych danych, wersja wiążąca proroka Jonasza z północną monarchią była w tradycji biblijnej powszechnie akceptowana. Czyniła ona z Jonasza nie tylko bohatera tej narracji, lecz także widziała w nim autora samej księgi.

Zwolennicy bardzo wczesnej tradycji literackiej obecnej w Księdze Jonasza opierają swoje stanowisko na dwóch argumentach. Pierwszy z nich dotyczy miejsca tego opowiadania $\mathrm{w}$ kanonie biblijnym. Wszystkie najważniejsze kanony biblijne zarówno hebrajski, jak i chrześcijański (katolicki i protestancki) umieszczają Księgę Jonasza pomiędzy utworami Abdiasza i Micheasza, których data powstania przypada również na VIII w. przed Chrystusem. Dodatkowo zwolennicy dawnej tradycji literackiej w Księdze Jonasza podkreślają, że twórcy kanonu poprzez umieszczenie w nim tego opowiadania wskazali pośrednio na autorstwo samego proroka. Księga Jonasza nie zawiera klasycznych wyroczni, a jednak znajduje się w zbiorze tzw. 12 proroków mniejszych. Nie byłoby to możliwe, gdyby sam Jonasz nie był głównym autorem tego dzieła. W tym kontekście należy również pamiętać o przepowiedni Jonasza z $2 \mathrm{Krl} 14,25$, która zwiastuje odbudowę Państwa Izraelskiego i przywrócenie jego chwały. Były to słowa, które wzbudzały szacunek wobec proroka w izraelskiej społeczności. Obecna w Księdze Jonasza krytyka jego osoby i piętnowanie jego wad pochodzą prawdopodobnie od samego autora, gdyż nikt inny poza nim samym nie odważyłby się krytykować jego zachowania.

Jak wynika z dotychczasowych obserwacji, teoria o powstaniu Księgi Jonasza zyskała sporą rzeszę zwolenników zarówno w judaizmie, jak w kręgach biblistów chrześcijańskich. We współczesnej egzegezie przeważa jednak pogląd, że zarówno autora Księgi Jonasza, jak i sam tekst opowiadania należy umieścić w epoce powygnaniowej, a fakty opisane w tym opowiadaniu nie mają nic wspólnego z wydarzeniami, które dokonały się z panowania Jeroboama II, czy też w okresie najazdów asyryjskich i związanych z tym deportacji w roku 732 i 722 przed Chrystusem. Przesłanki za tym, że tekst Księgi Jonasza stanowi świadectwo literatury charakterystycznej dla tzw. drugiego okresu perskiego ${ }^{8}$, kiedy trwał dyskurs na temat roli pogan w odradzającej się judzkiej państwowości, można oprzeć na trzech podstawowych przesłankach. Pierwszą z nich są

7 Zob. R. Zawadzki, The phrase hipîl gôralôt and the dating of Book Jonah, s. 463.

8 Por. C.E. Carter, The Emergence of Yehud in the Persian Period, s. 246. 
analizy wybranych elementów literackich (filologiczno-leksykalnych) występujących w opowiadaniu o Jonaszu, druga dotyczy studium źródeł zewnętrznych (biblijnych i pozabiblijnych), trzecią jest zaś przesłanie „teologiczno-ideologiczne" księgi.

\section{Argumentacja filologiczna}

Cechą charakterystyczną literatury hebrajskiej jest długi proces ustnego przekazu poszczególnych utworów biblijnych, zanim jeszcze otrzymały one ostateczną formę literacką $\mathrm{w}$ długim procesie redakcyjnym. Tym samym język zastosowany do spisania danego nie musi być odzwierciedleniem epoki, w której rzeczywiście powstał analizowany tekst. Język utworu to przede wszystkim świadectwo o tym, kiedy dany utwór został spisany i zredagowany, a nie kiedy powstał i był przekazywany z ust do ust. Księga Jonasza pod względem językowym wyróżnia się spośród innych ksiąg prorockich bardzo znacząco. W hebrajskim tekście opowiadania o Jonaszu uderza użycie dużej liczby arameizmów. Język aramejski jest dla wielu tak samo starożytny jak hebrajski.

Powszechnie uważa się jednak, że użycie języka aramejskiego i powolne zastępowanie nim języka hebrajskiego, jest charakterystyczną cechą epoki powygnaniowej za czasów Ezdrasza i Nehemiasza. Wspomnianych arameizmów w Księdze Jonasza jest sporo. Stanowią one niemal połowę tego typu słownictwa zastosowanego w pozostałych księgach prorockich razem wziętych. Do podstawowych terminów aramejskich występujących w tekście Księgi Jonasza należą:

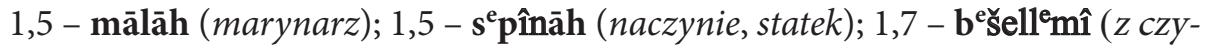
jego powodu); 4,11H pābāh (bardzo, licznie, wiele) $)^{9}$. W opowiadaniu o Jonaszu pojawiają się także późno-hebrajskie np. qerî’āh (pouczenie, napomnienie), które jest hapax legomenon w ST ${ }^{10}$ oraz tytul „Bóg niebios” (Jon 1,9) stosowany $\mathrm{w}$ literaturze judaistycznej w okresie perskim ${ }^{11}$. Według opinii W. Pikora, ję-

9 Należy pamiętać, że nie wszyscy egzegeci są zdania, że terminy te mają pochodzenie aramejskie. Taki pogląd istniał zwłaszcza wśród tych, którzy uważali Księgę Jonasza za dzieło pochodzące z VIII wieku przed Chr. Uważają oni, że rzekome arameizmy są przykładem dialektu fenickiego. Por. T. Brzegowy Miłosierdzie Boże nie zna granic (Księga Jonasza), s. 140; O. Loretz, Herkunft und Sinn der Jona-Erzählung, s. 24; S. Potocki, Ksiega Jonasza, s. 303.

10 Według P. Briksa do arameizmów epoki powygnaniowej należą także inne terminy występujące w tym opowiadaniu: “āšat $(1,6)$ : „wspomnieć” , „pomyśleć”; tā'at $(3,7)$ : „ogłoszenie”, „rozkaz”, mānah (2,1): „przygotować”, „posłać”. Por. P. Briks, Księga Jonasza jako element dyskusji nad założeniami reformy Państwa Izraelskiego w okresie perskim, s. 93.

11 Por. S. Potocki, Księga Jonasza, s. 294. 
zyk aramejski stał się głównym językiem imperium dopiero w VI wieku przed Chrystusem, czyli w Persji. Traktowanie go jako dominującego w Asyrii jest anachronizmem. W Palestynie epoki perskiej językami obcymi chętniej używanymi aniżeli hebrajski były: fenicki, maoabski czy edomski ${ }^{12}$.

Oczywiście samo pojawienie się $\mathrm{w}$ tekście Księgi Jonasza licznych arameizmów nie wyklucza ostatecznie możliwości zawarcia w niej świadectwa diasporze Żydów w Asyrii. W takim przypadku jednak należałoby oczekiwać przekazów i tekstów w językach charakterystycznych dla tamtej epoki (IX-VIII w. przed Chr.), jak ma to miejsce w dziełach Amosa, czy Ozeasza, którzy piękną i klasyczną hebrajszczyzną wpłynęli na twórczość późniejszych autorów ze środowiska deuteronomicznego ${ }^{13}$.

\section{Argumentacja historyczna}

Druga grupa przesłanek pozwalających ustalić w przybliżeniu pochodzenie i środowisko, w którym powstawała Księga Jonasza, opiera się na wskazówkach pochodzących z samej treści tego opowiadania. Dotyczą one ewentualnych danych historycznych i geograficznych, jakie można napotkać, śledząc perypetie Jonasza w kolejnych odsłonach jego dziejów. Na pierwszy plan wysuwa się tu sama Niniwa, starożytna stolica Imperium Asyryjskiego, do której dwukrotnie miał wyruszyć Jonasz. Jednak w czasach Jonasza, bohatera $1 \mathrm{Krl} \mathrm{14,25} \mathrm{nie} \mathrm{była}$ ona jeszcze stolicą imperium. Stało się to dopiero w latach 704-681, za panowania króla Sennacheryba, a więc już po upadku Samarii ${ }^{14}$. Trzeba zauważyć, że autor opowiadania o synu Amittaja mówi o tym mieście w czasie przeszłym. Była ona znana od czasów bardzo starożytnych. Sam Hammurabi uczynił z niej jeden z najważniejszych ośrodków swojej władzy. W późniejszych czasach Niniwa nabrała znaczenia dopiero w czasach Senaheryba I (704-681), ale jej czas świetności, bo tylko do roku 612 przed Chrystusem, kiedy to Medowie i Persowie doprowadzili do jej upadku ${ }^{15}$. Według danych historycznych przez cały ten czas mieszkańcy Niniwy byli wyznawcami politeizmu, chociaż ok. roku 800 przed Chrystusem król Adadnirari III próbował zaprowadzić w całym państwie reformę religijną zmierzającą do wprowadzenia monoteizmu. Nie był to jednak

12 Por. W. Pikor, W poszukiwaniu asyryjskiej diaspory Izraelitów w Księdze Ezechiela, s. 307-308.

13 Por. J.S. Synowiec, Prorocy Izraela, ich pisma i nauka, s. 173.

14 Por. W. Pikor, Słowo Boże jako źródło kryzysu proroka - przypadek Jonasza i Jeremiasza, s. 40.

15 Por. T. Tułodziecki, Jonasz wobec pogan, s. 42. 
kult Boga Jahwe, lecz wiara w bóstwo Nabu. Ten fakt nie był raczej znany autorowi Księgi Jonasza, podobnie jak i zwyczaje Niniwitów. Opisywane przez niego praktyki postne były raczej zwyczajem znanym w Egipcie i starożytnej Grecji, aniżeli w Asyrii16.

Także i współczesna archeologia potwierdza fakt, że autor opowiadania o Jonaszu pisał swój tekst długo po upadku asyryjskiej stolicy, a dokładne historyczne dane na jej temat musiały dawno zatrzeć się w świadomości autora Księgi Jonasza i jemu współczesnych. Fakt, że autor pisał swój tekst dziesiątki, a nawet setki lat po zburzeniu Niniwy, potwierdzają przesadzone dane na temat jej wielkości. Tekst wspomina o jednodniowym marszu Jonasza przez miasto, choć nakazane przez Boga były aż trzy (Jon 3,3). Miasto rozległe na trzy dni drogi musiałoby mieć promień ok. $90 \mathrm{~km}$, przyjmując, że dzień marszu dla dorosłego człowieka wynosi średnio ok. $30 \mathrm{~km}$. Odkryty przez archeologów zarys fundamentów zburzonego miasta pozwala oszacować jego długość na ok. $12 \mathrm{~km}^{17}$.

Przesadzona jest również liczba mieszkańców Niniwy, która idąc śladem danych biblijnych, musiałaby oscylować około miliona, jeśli samych dzieci, czyli jak mówi tekst Jon 4,11, tych, którzy nie odróżniają swojej prawej ręki od lewej, wynosiła aż 120000 tys. Bardzo istotnym faktem, w kwestii okoliczności historycznych powstania Księgi Jonasza, jest informacja o królu Niniwy. Dokumenty z epoki dominacji Imperium Asyryjskiego nazywają jej władców królami Aszur. Tytuł użyty w Księdze Jonasza nie był zatem znany na terenie Niniwy. Również fakt konsultacji decyzji króla o poście i pokucie z dostojnikami imperium nie był znany w epoce asyryjskiej, lecz charakteryzował zwyczaje dworskie w Persji. Wiadomości o nim Izraelici mogli zatem zdobyć dopiero po roku 538 przed Chrystusem. Jest to zatem świadectwo diaspory babilońskiej, a nie asyryjskiej ${ }^{18}$.

\section{Argumentacja teologiczna}

Najobszerniejszą grupę przesłanek wskazujących na dość późne powstanie Księgi Jonasza tworzą liczne nawiązania do charakterystycznych koncepcji teologicznych, jakie znamy z innych ksiąg biblijnych okresu perskiego i hellenistycznego. Paralelizm tematyczny istnieje przede wszystkim pomiędzy na-

\footnotetext{
16 Por. J.S. Synowiec, Prorocy Izraela, ich pisma i nauka, s. 454.

17 Por. U. Struppe, Bie Bücher Obadja, Jona, s. 118.

18 P. Briks, Księga Jonasza jako element dyskusji nad założeniami reformy Państwa Izraelskiego $w$ okresie perskim, s. 95.
} 
uczaniem Jonasza i proroka Jeremiasza. W obu przypadkach chodzi o motyw frustracji i rozczarowania, jaki przeżywają obaj słudzy Słowa, widząc bezowocność ich przepowiadania (Jr 15,10.17-19; 20,14-18). W tym przypadku mamy do czynienia ze stosunkowo późną tradycją literacką, sięgającą czasów najazdu babilońskiego, bądź już samej niewoli, zbieżną czasowo z tradycją deuteronomiczną. Stosunkowo łatwo można też dostrzec analogie pomiędzy historią Jonasza a wcześniejszym opowiadaniem o dziejach Eliasza. T. Brzegowy, powołując się na wcześniejsze badania A. Weisera, wskazuje, że historia Eliasza w $1 \mathrm{Krl}$ 19, w swojej pierwotnej wersji powstała w szkole prorockiej zgrupowanej wokół Jonasza, syna Amittaja z 2 Krl 14,25. Dodaje on również, że dawna tradycja żydowska identyfikowała jego samego z wskrzeszonym synem wdowy z Sarepty Sydońskiej (1 Krl 17,8-24), a także z anonimowym prorokiem, który namaścił Jehu na króla izraelskiego $(2 \mathrm{Krl} 9,1-9)^{19}$. Z czasem została również włączona do całości Dzieła Deuteronomicznego.

Psalm wygłoszony przez Jonasza we wnętrznościach jest aluzją do innych psalmów biblijnych, zwłaszcza tych, które poruszają tematykę szeolu. Jonasz swój stan ducha porównuje do tego strasznego miejsca, skąd głośnym wołaniem wzywa Boga. Szeol jest nazwą często w Biblii spotykaną (82 razy w BH) i określa przede wszystkim miejsce pobytu zmarłych, znajdujące się w najniższej części wszechświata. Przedstawiano go jako grób, otwór w ziemi, fosę lub studnię (por. Ps 30,10; Ez 28,8), najgłębszą, jaka może być w ziemi (por. Pwt 32,22; Iz 59,9) i sięgającą głębiej niż podziemne przepaści (por. Hi 26,5; 38,16). Jonasz zdaje sobie sprawę z tego, że człowiek może modlić się do Boga wszędzie, czy to we wnętrzu ryby, czy w żołądku/brzuchu szeolu ${ }^{20}$.

Motyw połknięcia przez rybę i przebywanie w jej wnętrzu jest obecny w literaturze hellenistycznej (333-63 rok przed Chr.). Potwierdzają to przede wszystkim liczne sagi greckie. Na ten czas historyczny, jako epokę powstania Księgi Jonasza, wskazuje także motyw postu, który podejmują mieszkańcy Niniwy w odpowiedzi na nauczanie Jonasza $(3,5)$. Egzegeza widzi w tej praktyce wyraźne nawiązanie do deuterokanonicznej Księgi Tobiasza, której datacja określana jest również na epokę helleńską ${ }^{21}$. W datowaniu Księgi Jonasza od dawna istnieje jednak jeden pewnik. W Księdze Syracha 49,10 autor użył określenia „dwunastu proroków”, pośród których na pewno jest miejsce dla Jona-

19 Por. T. Brzegowy, Heksameron i inne studia nad Starym Testamentem, s. 606.

20 Porównanie obrazu Szeolu i innych starożytnych wyobrażeń krainy umarłych, zob. J. Lemański, Hebrajski Szeol na tle wyobrażeń eschatologicznych sąsiednich kultur, s. 67-97.

21 Por. J.S. Synowiec, Prorocy Izraela, ich pisma i nauka, s. 458. 
sza. Opowiadanie o nim musiało powstać przed ostateczną redakcją Syracydesa, czyli pod koniec III lub na początku II wieku przed Chrystusem ${ }^{22}$.

Istotną rolę $\mathrm{w}$ ustaleniu datacji Księgi Jonasza odgrywa jej podstawowe przesłanie teologiczne. Choć przywoływany wielokrotnie w tej publikacji T. Brzegowy twierdzi, że uniwersalizm zbawienia jest tak stary jak biblijny Izrael $^{23}$, to jednak szczególnie silne wybrzmiewa w księgach biblijnych pochodzących z epoki powygnaniowej. Pierwsze poważne wypowiedzi na temat zbawienia pogan pojawiają się $\mathrm{w}$ niektórych księgach prorockich, przede wszystkim Deuteroizajasza (Iz 42,10-12; 51,4-6; 55,5), który tworzył na wygnaniu babilońskim w VI wieku przed Chrystusem. Zbieżność tematów teologicznych widać również także pomiędzy Jonaszem a Księgami Ezdrasza i Nehemiasza. Chodzi tu o pozytywne spojrzenie na zachowanie pogan u proroka (marynarze na okręcie, mieszkańcy Niniwy), które polemizuje z wybitnie separatystyczną wizją świata ukazaną w powygnaniowych dziełach wielkich reformatorów Izraela: Ezdrasza i Nehemiasza. Opowiadanie o Jonaszu, podobnie jak Księga Rut byłaby świadectwem o dyskusji, jaka toczyła na przełomie V i IV wieku przed Chrystusem nad rolą ludzi obcego pochodzenia w odrodzonej po niewoli społeczności żydowskiej.

\section{Podsumowanie}

Wszystkie przytoczone argumenty nie dają całkowitej pewności co do precyzyjnej i pewnej datacji Księgi Jonasza. Służą jedynie jako zbiór przesłanek, dzięki którym większość egzegetów przyjmuje za bardziej prawdopodobną hipotezę o powstaniu dzieła Jonasza w epoce sprzeciwu przeciwko nacjonalizmowi i izolacji Żydów za czasów Ezdrasza i Nehemiasza. Ze względu na przytoczone przesłanki natury filologicznej, historycznej i teologicznej możemy przyjąć, że Księga Jonasza powstała pomiędzy rokiem 539, czyli datą wydania dekretu Cyrusa kończącego niewolę babilońską, a rokiem 200 przed Chrystusem, który zamyka okres panowania ptolemejskiego na starożytnym Bliskim Wschodzie ${ }^{24}$. Wydaje się, że treść księgi najbardziej odpowiada stosunkom społeczno-politycznym panującym w Imperium Perskim. O ewentualnych śladach diaspory asyryjskiej, w której mógłby żyć, czy działać biblijny Jonasz, tekst jego księgi milczy.

22 P. Briks, Księga Jonasza jako element dyskusji nad założeniami reformy Państwa Izraelskiego $w$ okresie perskim, s. 96.

23 Por. T. Brzegowy, Heksameron i inne studia nad Starym Testamentem, s. 614.

24 Por. W. Stabryła, Orędzie prorockie w Księdze Jonasza, s. 295-296. 


\section{Bibliografia}

Briks, P., Księga Jonasza jako element dyskusji nad założeniami reformy Państwa Izraelskiego $w$ okresie perskim, SBO 1/2009, s. 91-106.

Brzegowy, T., Heksameron i inne studia nad Starym Testamentem, RSB 45, Warszawa 2012.

Brzegowy, T., Miłosierdzie Boże nie zna granic (Ksiega Jonasza), w: J. Frankowski, Wielki świat starotestamentalnych proroków I. Od początków profetyzmu do Niewoli Babilońskiej, WMWKB 4; Warszawa 2001, s. 129-152.

Carter C. E., The Emergence of Yehud in the Persian Period. A Social and Demgraphic Study, JSOT.S 294; Sheffield 1999.

Lemański, J., Hebrajski Szeol na tle wyobrażeń eschatologicznych sąsiednich kultur, SBO 3/2011, s. 67-97.

Loretz, O., Herkunft und Sinn der Jona-Erzählung, BZ 5/1961, s. 18-29.

Pikor, W., Słowo Boże jako źródło kryzysu proroka - przypadek Jonasza i Jeremiasza, AK 154/2010, s. 31-60.

Pikor, W., W poszukiwaniu asyryjskiej diaspory Izraelitów w Księdze Ezechiela, ZNSBP 9/2012, s. 285-334.

Potocki, S., Księga Jonasza. Wstęp - przekład z oryginału - komentarz, w: Pismo Święte Starego Testamentu. Księgi proroków mniejszych. Wstęp - przekład z oryginału komentarz, t. XII-1, Poznań 1968, s. 285-341.

Stabryła W., Orędzie prorockie w Księdze Jonasza, w: W. Chrostowski, Jak śmierć potężna jest miłość (Pnp 8,6). Księga pamiątkowa ku czci Księdza Profesora Juliana Warzechy SAC, Warszawa 2009, s. 394-418.

Struppe, U., Bie Bücher Obadja, Jona, NSK 24/1, Stuttgart 1996.

Synowiec, J. S, Prorocy Izraela, ich pisma i nauka, Kraków 1999.

Tułodziecki, T., Jonasz wobec pogan, BPTh, 2/2009, s. 37-48. DOI: http://dx.doi. org/10.12775/BPTh.2009.002.

Zawadzki, R., The phrase hipîl gôralôt and the dating of Book Jonah, w: M. Wróbel, Deus meus et omnia. Ksiega pamiątkowa ku czci o. prof. Hugolina Langkammera OFM w 50 rocznicę święceń kapłańskich, Lublin 2005, 463-471.

Zenger, E., Das Zwölf Prophetenbuch, w: idem, Einleitung in das Alte Testament, Stuttgart-Berlin-Köln $1996^{3}$, s. 467-533. 